\title{
The Essence of Ethical Leadership and Its Influence in Achieving Employees' Job Satisfaction
}

\author{
Mohammed Nazeer Ahmed
}

$\mathrm{PhD}$ in Human Resource Management, Senior Faculty member, Business Studies Department, Salalah College of Technology, Sultanate of Oman

\begin{abstract}
This study strongly conveys that, ethical practices have to be followed by organizations to ensure employees' job satisfaction, achieving employees' job satisfaction is essential for the success and longevity of the organizations. The research structurally consists of four sections. The first section deals with the essence of ethical leadership explaining the need and benefits associated with businesses from ethical practices. The second section defines the ethical factors, which if not taken into account reduce the effectiveness of leadership, the typical ethical mistakes of managers, which leads to a reduction in the transparency of relationships in the team, discourages creative thinking and forms a negative working environment (indifference to employees, delay in wage payments, inhibition of career opportunities for workers, unfavorable conditions for increasing the labor productivity, etc.). The third section, deals with the prerequisites of ethical leadership (honesty in relations with employees, clients, shareholders and the public, integrity and consistency, balance of relations, consistency of standard expectations and real attitude to work, compliance with guarantees and obligations, loyalty of management to employees and vice versa - employees to the company, taking into account not only the financial, but also the emotional long-term effects of business decisions, etc.). The fourth section explains the role of ethical leadership in maintaining employees' job satisfaction. The author points out that, for achieving the employees' job satisfaction, leaders should remain aware of the real, rather than formal, reasons for employees' dissatisfaction, create a dynamic stress-free work environment, stimulate the development of the common interests of the staff/managers, motivate employees to communicate fearlessly the matters concerning the job, take a proactive intermediary position in working conflicts, etc.. Within each of these sections, the author summarizes the methodical achievements of the researchers from different countries of the world, as well as defines the applied ethical practices that can be applied by the leaders of different companies, regardless of a sector specificity and a dominant type of management.
\end{abstract}

Keywords: the essence of ethical leadership; causes for leadership failures; prerequisites of ethical leadership and the role of ethical leadership.

JEL Classification: A13, D63.

(C) The Author, 2018. This article is published with open access at Sumy State University.

\section{Introduction}

\section{What is Ethical Leadership?}

Leadership is the art of persuading the followers, to do certain activities or tasks, that has been set as goals to be achieved, the goals could be either political, organizational or corporate related, irrespective of the requirements, the leader as a protagonist, shall persuade his/her followers towards achieving desired goals. The role of the leader is to provide direction and motivation to individuals towards the desired goal (Katarina et al, 2010: 32). A great leader is not just the one who influences his/her followers but one who could instill ethical behavior and creates a high-performance organization. Great leadership achieves positive, substantiate and sustainable results through people or employees in an organization (James and Don, 2010: 190).

Brown et al (2005: 120) define "ethical leadership here as the demonstration of normatively appropriate conduct through personal actions and interpersonal relationships, and the promotion of such conduct to followers through two-way communication, reinforcement, and decision-making". According to the Brown et al, the ethical leader is a leader with qualities such as honesty, trustworthiness, fairness and care towards his/her organization and followers, making him/her be a legitimate and credible role model.

To achieve the ethical standards, ethical leaders should frequently communicate with their followers for providing them clarity and ensuring that they are not deviating from the set standards. The essential 
characteristic of ethical leaders is they act as proactive role models of ethical conduct (Brown and Treviño, 2006: 597).

The methodology of the study: Data for this study were drawn from a review of secondary sources. The literature for this study has been presented in four different sections. Section I deals with the essence of ethical leadership, it deals with the need for ethical leadership and it elaborates on the benefits associated to businesses for following the ethical practices. The subsequent section, i.e., Section II specifies, why leadership fails, it explains the causes of leadership failure. Section III deals with the prerequisites of ethical leadership, it presents comprehensively, the preconditions, which are required to confirm a leader, as an ethical leader. The last section, i.e., Section IV emphasizes on the role of ethical leadership in achieving employees job satisfaction, this section points out the causes of employees' job dissatisfaction that the leaders should remain aware and also focuses on the best ethical practices that are to be followed to achieve employees' job satisfaction.

\section{Section I: Essence of Ethical Leadership}

\section{Need for ethical leadership}

The term ethics is understood from two important dimensions firstly, ethics refers to well-founded standards that prescribe what is right and what is wrong? Ethics prescribes what humans ought to do in terms of rights, obligations, benefits to society and justice and fairness. Ethics refers to those ethical standards that impose reasonable obligations to refrain from crimes and frauds. Ethical standards include those standards that enjoin virtues of honesty, compassion and loyalty, not to lie, not to exploit employees or the natural resources, fair trade, saving the Planet, etc. Secondly, ethics refers to the continuous effort of studying one's own ethical standards, moral beliefs and moral conduct and striving to ensure that we as individuals/organization live up to standards that are reasonable and solidly-based (Velasquez et al, 2010).

The leadership is said to be ethical when it could favor good governance. The essence of good governance is to fight against fraud and corruption and shall assist in achieving the organizational and individual goals. Good governance is fundamentally about honesty, trustworthiness, diligence, transparency, competence and fairness. Good governance is possible through ethical leadership. There is an urgent need in societies to encourage and promote ethical leadership supported by a strong moral code of conduct. The essential characteristic of a leader of any institution, whether in government or a private company, supposed to have is integrity, trustworthiness, transparency and equity (V. Mungunda, 2015).

\section{Benefits associated to businesses for following ethical practices}

Following the code of ethics is an integral part of an ethical organization. Therefore, every organization for its success must actively promote ethical policies and procedures and shall initiate programs to ensure awareness among employees and their commitment towards ethical practices.

Figure 1 displays the benefits available to businesses for following ethical practices.



Figure 1. Benefits to Businesses

Ethical firm contributes improvement to the society and enjoys its patronage: The members of the society give the firms or businesses the legal recognition to existing. Every business firm uses the society's scarce resources such as land, raw materials and services of skilled employees. In true sense, the firm owes an obligation to the society in which it exists. This would imply that business organizations are expected to create wealth, generate income and enhance the social welfare of the society in which it dwells. An ethical organization endeavors to honor its obligations towards the society by producing goods/services and creating wealth. Ethical businesses generate incomes to the society by providing employment opportunities. Further, ethical businesses enhance social welfare through increased economic efficiency, improved decision-making 
process, acquiring and utilizing the advanced technology and equipment, stable channels of distribution and sales of products to the consumers at a competitive price. These ethical efforts of the firm would result in enjoying the patronage of members of society (Fernando, A.C., 2010: 2.13).

High productivity and strong teamwork: In common, the disparity exists between preferred values and the values actually reflected by the behaviors of the employees at workplace. Such disparities if not checked would result in chaos, affect the production, and would have a direct impact on sales and revenues of the business. An ethical organization would focus its attention on imparting ethical programs to employees so that there is proper alignment between the preferred values at the organization and values reflected by the behaviors of employees. In simple, a focus on the expected values in the workplace would build integrity among employees. When employees feel the strong alignment between their values and those that are expected by the organization, they react with strong motivation and performance this leads to the high productivity and strong teamwork (Larry, 2006: 111).

Ethical policies and practices create a strong public image of the company: Ethical organizations establish policies and practices that ensure all employees are treated fairly and ethically. For the existence of an ethical environment, companies, usually develop an ethical philosophy and implement it with specific guidelines to ensure that the policies and practices are uniformly followed (Mohanty, 2008: 421).

Ethical practices help to resolve ethical dilemmas at a workplace: Often, employees are encountered with the risk of facing the ethical dilemma. Ethical dilemmas can be more challenging and critical. An organization practicing ethical policies and procedures focuses on overcoming ethical dilemmas by assisting employees through educational programmes, which insist employees consult company code of ethics for formal guidance and this will avoid confusion and provide clarity. Further, ethical programmes provide the opportunity to the employees to seek guidance from their immediate supervisor to learn from their experiences and knowledge, ethical programmes create the ethical climate. A.C. Fernando, (2010: 9.8) suggests that "It is necessary that each company puts in place an ethics programme and makes it known to all its employees so that they know its values, mission and vision and comply with the policies and code of conduct, all of which create its ethical climate".

Corporate reputation: Ethical practices help firms to achieve a good corporate reputation. A firm is said to have achieved corporate reputation, particularly, when its customers prefer doing business with the firm, even though similar products and services are available in other companies' at similar cost and quality. Corporate reputation is earned by the companies with the support of all the stakeholders, most particularly, the customers and employees. Riccardo (2002: 28) defines "Organizational scholars see corporate reputation as rooted in the experience of employees. A company's culture and identity shape a firm's business practices as well as the kinds of relationships that managers establish with key stakeholders".

\section{Section II: Why Leadership Fails?}

Leadership is the result of what a leader does. The action taken by the leader is actually the inner vision and basic character the leader has. The success of leadership depends on various factors arguably; one of the essential factors is influencing the employees because influencing employees infuses commitment among them. The commitment would help employees to give their free time in solving day-to-day problems, serving and satisfying customers, and to think creatively both for the betterment of the organization and for themselves. With influential leadership, employees perform better. Better leadership will allow employees to work collaboratively across the organizational lines, it will allow liberty to voice their opinions and authorize them for healthy open discussions on important matters involving health and future benefits in an organization.

Leaders who are great at listening to diverse opinions can create a positive working environment, such leaders can remove obstacles and provide effective means to employees to perform their jobs effectively. Influential leaders create environments that are trustworthy, collaborative with openness and sharing. Sadly, the derailment of leadership would take place in the organization, if a leader gets distracted from his/her objective for the numerous reasons. Some of the reasons that may result in the failure of leadership are presented in this study.

Figure 2 shows the major causes for leadership failure. 


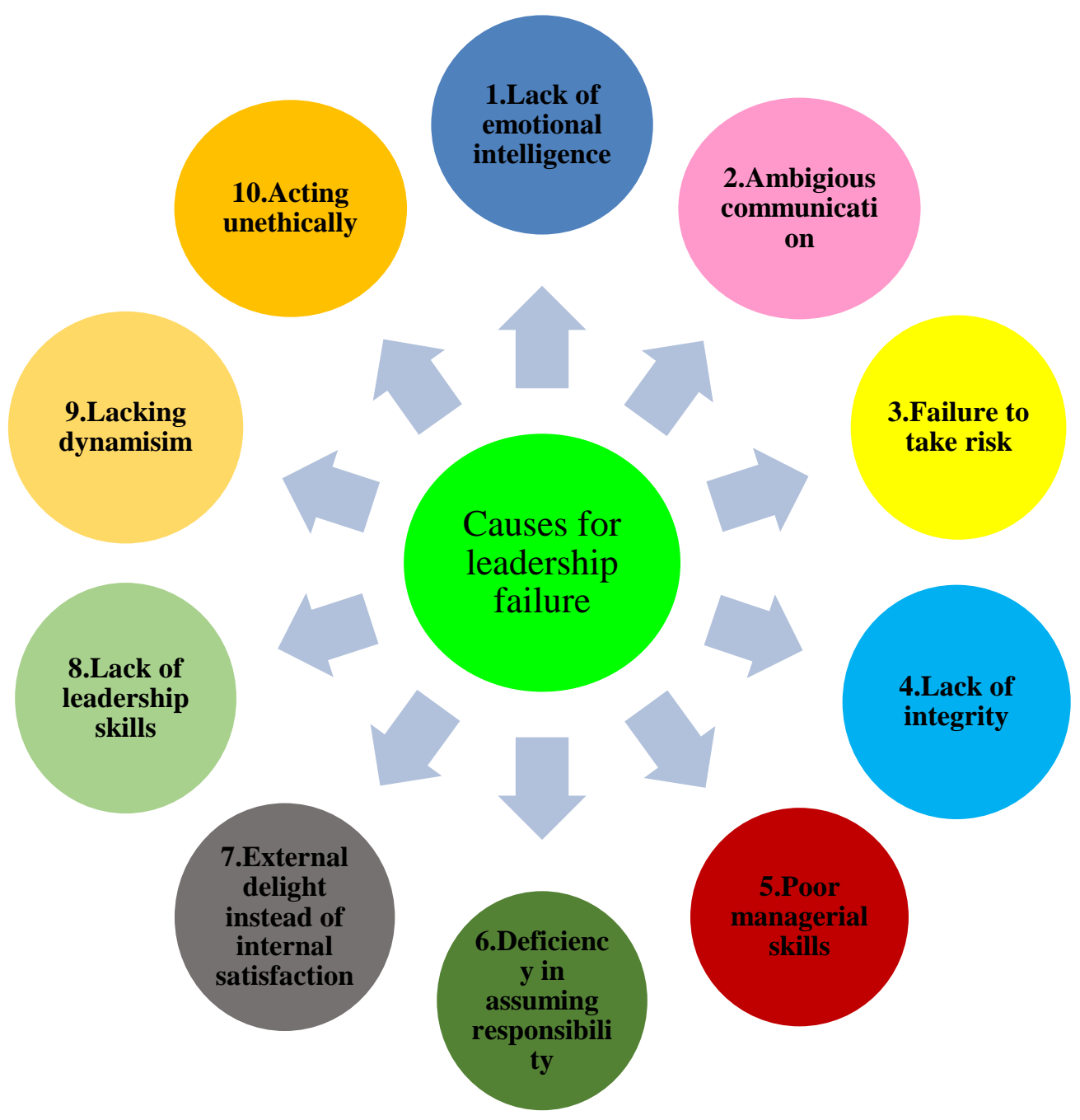

Figure 2. Causes for Leadership failure

Lack of emotional intelligence: Emotional intelligence helps an individual to monitor and control one's feelings; helps to deal matters with wit and etiquette that would be liked and appreciated by one and all. Mastering emotional intelligence helps augment normal intellectual workings. Essentially, a leader could be a genius, but handling subordinates concerns and grievances without emotional intelligence he/she can unsurprisingly fail as a leader (Adam Lee, 2002: 267). Leaders being human often may face difficulties with their thinking abilities, but they are often assumed by subordinates to think big. But when their emotionality does not correlate with subordinates sensibilities this would have an adverse effect on leadership.

Ambiguous communication: When the attention of leaders shift, this will result in being unclear about their own and organizational purposes. When the leaders lack understanding for their own purpose they communicate ambiguously with their followers, this will create confusion to followers as the intent of the leader is not easily understood by them. Confusion among followers will become the main reason for the lack of commitment among them. When leaders fail to effectively communicate, organization's valuable time and energy are wasted because the task or assignment will have to be redone. As the organization pays to its employees for the work done, redoing the work will be a costly affair it would adversely impact the financial results of the organization (Gregory, 2016: 21-22).

Failure to take risks: The human tendency is to fear while facing the pressures in life. Leaders who lack the desire to succeed would develop a fear of failure. When engrossed with fear of failure, leaders lose the ability to take reasonable risks. Lack of risk taking abilities will result in redundant leadership skills and would not support for innovations and this will be the cause of leadership derailment. Leadership derailment occurs, when there is no connectivity between the skills and competencies of the leader and the qualities required for higher job responsibilities (Benjamin, 2013: 80). 
Lack of integrity: Leadership is highly dependent on a leader's integrity. Integrity is possible through a leader's competency and good character. When the character of a leader diminishes his/her integrity ceases. When integrity ceases this is the sure sign of failure. Arif and Brian (2013: 107) opine that "Leaders are always seen as strong figures and examples to the employees. Therefore, leaders who carry good leadership characteristics will benefit the organization and become an icon within the team". When leader integrity is strong he/she can influence individuals and groups, motivates them to achieve common goals. With integrity, he/she can define values, norms and maintains the organization's persona.

Poor managerial skills: Leaders are often perceived to be humans with unlimited energy levels. Leaders will meet their disasters when they lack enthusiasm. Lacking enthusiasm will fail them to take care of their physical and emotional needs, which would result in a failure of leadership and would badly affect the team spirit. Ade et al (2016: 262) suggest that "Leadership is a relationship, authority and respect, which can be improved in various ways. Effective leaders maintain teamwork. That refers to all skills as a "people person"'. Therefore, the effective human, social and technical skills that a manager exhibits in teamwork will confirm about his/her efficient leadership.

Deficiency in assuming responsibility: A successful leader will delegate only the task but not the responsibility, because delegating both the work and responsibility will not reduce the leader's responsibility. Even if a leader has delegated responsibility along with authority for motivating the worker yet the leader remains accountable for the results. A leader when delegates the task and assume that he/she is not responsible for the results is not an efficient leader. John et al (2004: 323) suggest that "the simple act of delegating the work, and the authority and responsibility for performance, does not reduce the leader's responsibility or overall authority for the success of the team".

External delight instead of internal satisfaction: Leaders who prefer external pleasure instead of internal satisfaction will lose their ground and followers. Such leaders who work not for their inner satisfaction but rather for their personal means will reject the constructive suggestions by honest critic and love to be surrounded by people who tell them what they prefer to listen. In organizations, when the results are achieved, and if the leader begins to believe that, the success is because of his/her efforts rather than collaborative efforts, this is the sure sign of distorted leadership. For the successful leadership, leaders shall possess a strong future orientation, shall remain unbiased, show commitment to both personal and organizational improvement, shall remain focused towards innovation, ensure sustainability and continuity of proven practices, uncompromising approach to drive necessary changes (Mark, 2009: 85).

Lack of self-leadership skills: It is very essential on part of the leader to exercise self-leadership. A leader cannot be an effective person to guide others if he/she lacks self-leadership skills. To master over selfleadership skills, a leader shall first know him/her, should be able to control and communicate core organizational values, expectations and beliefs to employees. A leader cannot influence his followers if he/she has not done self SWOT-strengths, weaknesses, opportunities and threat analysis. The success of leadership is possible when employees' engagement is having a positive association with their perception of leadership styles in their immediate boss. Positive perception of leadership styles among employees is possible when leaders embrace visionary leadership instead of classical or transactional leadership style. Ahmad Zairy et al (2013: 94) argue that "Employee engagement is perceived as subsuming negative outcome from the employees when the supervisors are adopting classical or transactional leadership styles. Whereas when the leaders are embracing visionary and organic leadership, employee engagement is regarded as having a positive association with the employees' perception".

Lacking dynamism: An effective leader would watch for changing marketing trends, technological changes and its impact on business, a potential threat to the organization and difficulties that may hinder an organization's success, otherwise he/she is not an effective leader. The success of a leader is measured from the point of view as to how much influence he/she could make on individuals or group to achieve common goals. Naser et al (2016: 130) argue that "Leadership is defined as an organized process that influences an organizational group to achieve a common goal or specific targets".

Acting unethically towards their followers: Some leaders lack the skills and abilities to make the right choice. Ineffective leaders do not know that their doings are wrong. Some leaders do not understand the significance of virtues in business and may not distinguish between a right and wrong act. These poor leadership skills will result in acting unethically with their followers. Sometimes leaders face challenging motivations or weakness of will and would develop a narrow framing of what leadership and ethics supposed to be. Some leaders do not understand the connective link between them and followers, when leaders could not inspire their followers 
they cease to be leaders (Olsson Center for Applied Ethics, 2012). Ineffective leaders lack the understanding to identify the cause of problems in the organization. They blame their followers for any difficulties that arise in the organization; their ineffective managerial actions could unreasonably blame innocent employees as accused.

\section{Section III: Prerequisites of Ethical Leadership}

This section presents an understanding of the prerequisites of ethical leadership it provides the basic preconditions to consider a person's leadership as ethical leadership.

Figure 3 represents the basics prerequisites of ethical leadership.

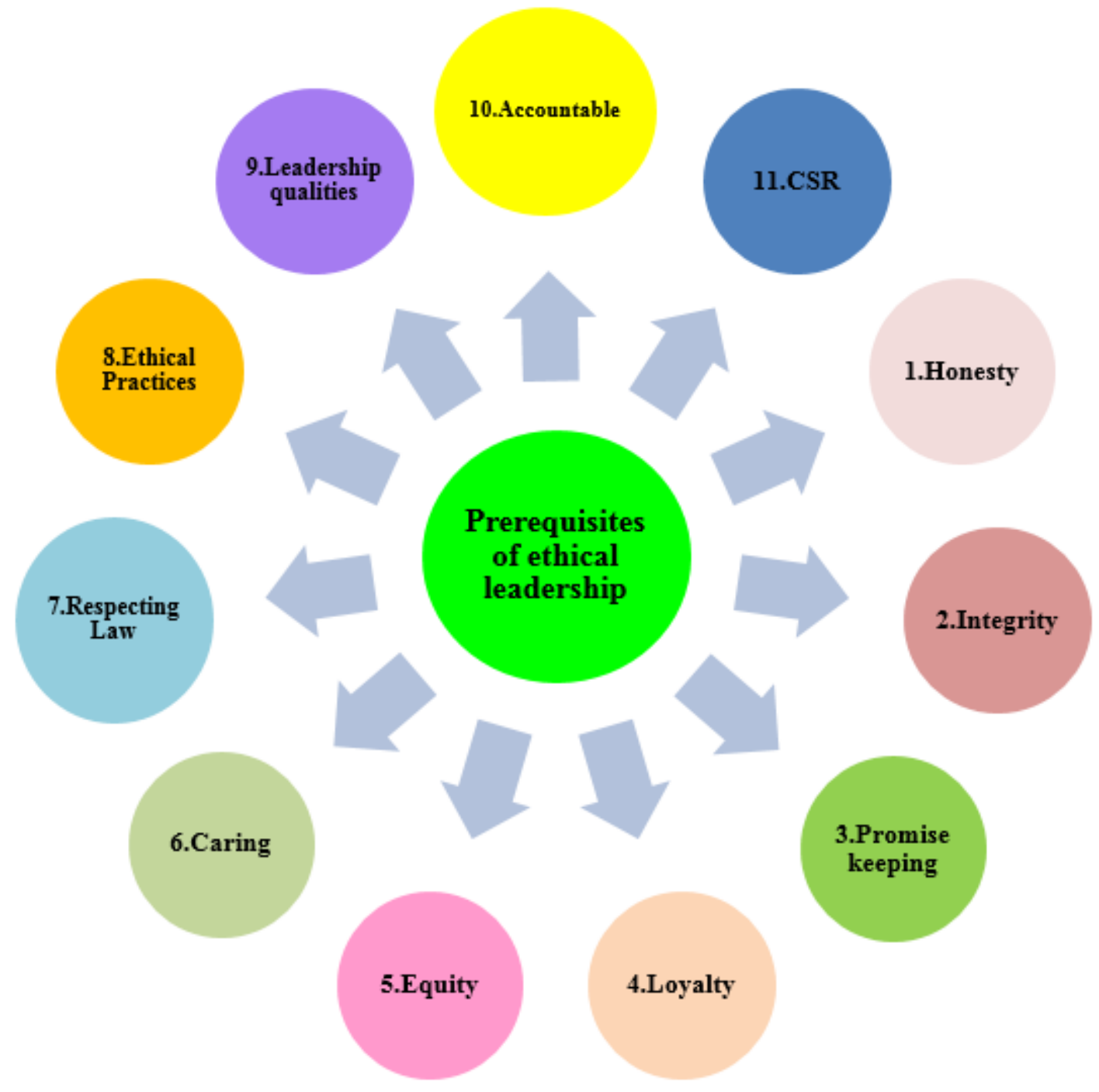

Figure 3. Prerequisites of ethical leadership

Honesty in actions: Organizations/Businesses need to be honest in all their actions particularly, in every communication. Society appreciates the fact when businesses are trustworthy and do not deceive their customers by either misrepresenting the facts or exaggerating the facts and this is possible when leaders leading the firm are honest and ethical. Richard, (2015: 40) believes, "Effective leaders are ethical leaders. One aspect of being an ethical leader is being honest with followers, customers, shareholders, and the public, and maintaining one's integrity. Honesty refers to truthfulness and non-deception".

Integrity and its consistency: Employees' integrity towards works represents the company's integrity towards society. Integrity means having a consistent personality that is validated through proper alignment of standard expectations and attitude towards work, customers, superiors, suppliers, and in whole towards society. Employees' integrity is directly related to leaders' integrity. Sam Eldakak (2014: 32) says, "Integrity is the 
pillar of the ethical code of conduct which assists a leader in maintaining balanced relationships and also motivates the leader to uphold moral values in daily activities".

Promises keeping and building trust: Organizations are expected to build trust by fulfilling the promises made to other businesses such as suppliers and vendors. The trust the company builds and commitment that the company honors attracts the other businesses to do business. The trust of the business is earned and retained only when the leaders practice and display trustworthy acts. Jeffrey (2015: 89) opines promise-keeping as "Adhering to the organization's stated values is, in ethical terms, promise keeping".

The sense of loyalty: Ethical businesses through effective and ethical leadership instill the sense of loyalty among their employees, so that, the employees remain loyal to both the company and to their team. When employees demonstrate loyalty, the trust is build up at the workplace. Jean and Gully (2014: 85) "Loyalty refers to a person's commitment to another person, task, or organization". Apparently, loyalty drives a person to remain ethically sensitive and motivates them to follow ethical policies, rules and behavior.

Fairness, justice and equity: Ethical leadership creates an environment, where no superior would take undue advantages of subordinates difficulties and mistakes. The ethical organization focuses on achieving fairness, equity and justice. Pravin, (2010: 620) opines "when individuals practice ethical values within an organization, it does not mean that the entire organization is ethical. Only when the entire organization practices fairness and justice in a systematic way can it be called an ethical organization. The foundation of the ethical organization is mutual trust and respect".

The sense of caring: Businesses through ethical leadership always consider the financial, emotional and longterm business consequences of an action. When businesses take care for the welfare of their stakeholders, sense of caring is developed this would render the firm ethical. Caring employees would boost the morale of employees. The sense of caring is the important aspects of an ethical conduct (David, 2013: ix).

Respecting law: Law is above all, organizations progressing through ethical leadership will never break the rules; an ethical organization always obeys the law related to the business activities. For the survival of businesses, profits are essential, the inflow of revenues is required to meet not only the day-to-day expenses of the business but also for the future expansion plan. However, profits should be earned through legal and ethical manner and this is possible if the leadership is ethical. Praveen \& John (2013: 522) observes that "Businesses must conform to laws and regulation as part of the contract between business and society that allows them to operate. This is now called a license to operate".

Ethical practices and respect towards cultures: Businesses through ethical leadership delivers the highest quality of service or products to their customers and focuses on constant endeavors for improvement in product and services. These practices brand the businesses as ethical firms. Being ethical signifies about pursuing excellence in everything that business does. Businesses should respect cultural diversity and treat customers, suppliers, employees and vendors with respect. Giving respect is essential because every stakeholder deserves dignity. Advances in communication and technology has minimized the world's borders. This has created a new global economy, which has resulted in bringing people together from countries with different cultures, values, laws, and ethical standards. International businesses must understand the values, cultures and ethical standards of their own countries and shall also remain sensitive towards other cultures. This will result in the sense of trust and respect (Ferrell et al, 2015: 276).

Good leadership qualities: Businesses shall create an ethical environment, in which decisions are made on values and ethical standards; this is possible if the leaders are ethical. Katarina et al, (2010: 33) recommend about the qualities the ethical leaders supposed to have, according to them, "The appropriate and desired behaviour is enhanced through culture and socialization process of the newcomers. Employees learn about values from watching leaders in action. The more the leader "walks the talk", by translating internalized values into action, the higher level of trust and respect he generates from followers". Therefore, leaders must and should have ethical qualities to inspire their employees.

Accountable for stakeholders: Businesses to remain ethical shall endure accountability. Ethical leadership allows the firm to take up accountability for every of their action that relates with their employees, suppliers and community. Mollie and Patricia (2008: 38) say "Accountability is not an obsolete concept in contemporary business life. The notion of accountability will remain meaningful and significant in business ethics discourses". 
Corporate Social Responsibility: Ethical leadership through its ethical practices supports and develops transparency in all matters; including employee-related matters, and this will favor companies in attracting and retaining the best talents. Atiya et al (2015: 112) observe that "The role of ethical leadership in influencing the performance of the employees rests on the pedestal of behavioral motivation, inspiration and individualized consideration". It is to be noted that, to retain the best talent, the ethical leaders have to focus on job satisfaction of employees. Although, motivating and inspiring employees is an essential task of companies but on a broader perspective, the leadership must and should satisfy all its stakeholders such as lenders, government, employees, suppliers and customers etc. Satisfying all the stakeholders is possible if businesses concentrate to contribute to acceptable development by initiating strategies related to corporate social responsibility (CSR). The CSR is an innovative business concept that contributes to justifiable development by delivering economic, societal and ecological benefits for all its stakeholders. Ramon Mullerat (2010: 14) elucidates that, "Through CSR, companies voluntarily decide to respect and protect the interests of a broad range of stakeholders while contributing to a cleaner environment and a better society through an active interaction with all". CSR is essential to businesses for its success and existence, even though if a company proceeds with a superficial understanding of social responsibility, yet it has to include the topics of environmental protection, economic indicators, sponsoring quality control, occupational health and safety (Tóth, 2009: 18). To the businesses, the importance of CSR remains essential because it emerges from the ethical responsibility of the organization.

\section{Section IV: Role of Ethical Leadership in Achieving Employees' Job Satisfaction}

Ethical leaders are perceived as having a broad ethical awareness and concern for all stakeholders, in this context, most particularly the employees. For developing responsibility among employees, leaders must create a friendly work environment, communicate ethical issues and shall serve as a role model for an ethical environment to remain and continue. Essentially, those leaders who exhibit ethical behavior would be more likely to consider the needs and rights of employees and treat them with equity and justice (Shukurat, 2012: 234). Certainly, employees prefer to work for a responsible employer or leader. The satisfaction of employees is achieved by the leaders by winning the confidence of employees. However, the confidence of employees is achieved by the leaders only after fulfilling ethical obligations towards their employees.

Employees' job satisfaction: It denotes how cognitively the employee is content with his/her job. This includes liking of the job, nature of work environment, nature of work supervision etc. Employee satisfaction is not that simplistic, as it is perceived instead it is focused on multidimensional psychological responses, it reflects the emotional state of the employee towards various factors involved in his/her job. The study conducted by Kooskora, M. and Mägi, P. (2010) to find the relations between "ethical leadership behavior and employee satisfaction", conclude that ethical leadership is positively associated with employee job satisfaction. According to their study, the impact of ethical leadership behavior has a positive impact on employee satisfaction. The study suggests that, the impact of ethical leadership can result in employee trust, loyalty towards organization and leaders, pride about the company, organizational commitment, workplace environment and organizational climate, employee recognition and empowerment, awareness of the organizational activities, and participation in decision making (Kooskora, M. and Mägi, P., 2010: 10). In order to guarantee employees satisfaction, leaders should remain aware of the specific causes of employees' job dissatisfaction and shall also know about the practices that will contribute to the employees' job satisfaction.

This present section IV elucidates the causes of employees' job dissatisfaction and also focuses on the best ethical practices that are to be followed to achieve employees' job satisfaction.

1. Causes of employees' job dissatisfaction: Essentially, leaders should remain aware of the causes which result in employees' job dissatisfaction. Knowing the causes and overcoming the causes help leaders instilling confidence among employees.

Figure 4 represents the main causes that result in employees' job dissatisfaction. 

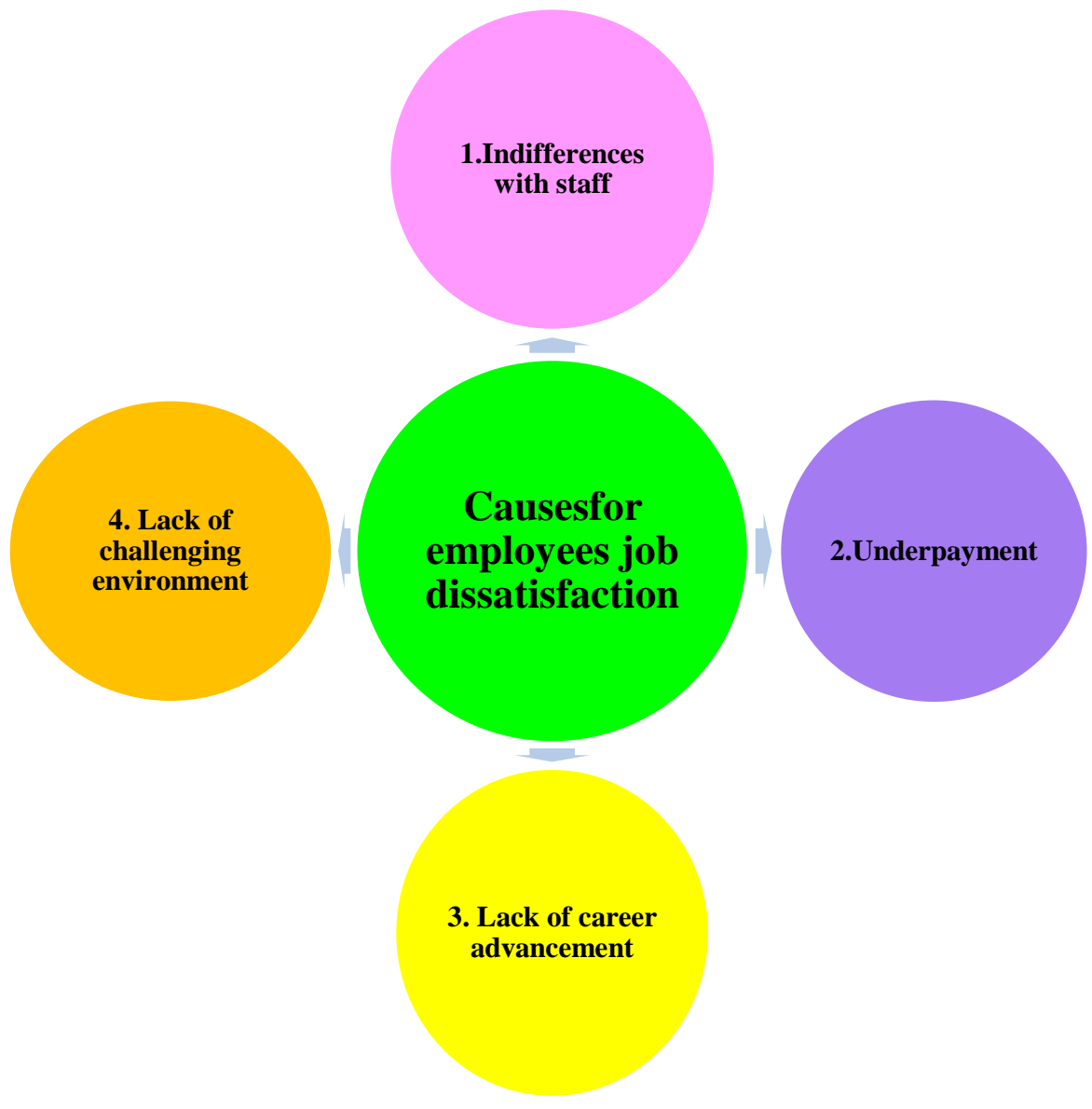

Figure 4. Causes of employees' job dissatisfaction

Indifferences with staff: The major imperfections that are associated with poor leaders are contradictory promises, indecision, failure to deliver the expectations that were benchmarked by themselves, inflexibility in thoughts and actions and developing indifferences with staff etc. Poor leaders can easily frustrate even the motivated employees (Ludger, 2012: 52). Leaders shall remain flexible in their thoughts and actions and shall avoid developing indifferences with their staff.

Underpayment: Payment of salaries and other benefits should correspond to educational qualifications, work experience, skills and abilities of employees. If employees are underpaid, they would have to undergo stress in paying monthly bills with a limited source of income; this will surely cause job dissatisfaction. Ranulfo and Orlando (2003: 25) suggest that "The employee may be satisfied when pay is commensurate with the relative difficulty and importance of the job". To ensure employees remain motivated, it is essential that, the payment of salaries and other benefits should be proportionate to the hard work the employees undergo for completing the tasks at workplace.

Lack of career advancement: Employees feel motivated when their boss include them in long-term plans and give them valued appreciation through promotions. Promotions given to employees will help them to remain associated with the company and also help them to remain successful in achieving their long-term plans. But when there is a lack of career advancement employees would get dissatisfied and become less motivated to achieve productivity. Career advancement is an important tool for motivation when employees are promoted, they are motivated. It not only provides them with additional financial benefits but would also help them to develop a feeling that they have mastered the previous levels (Gary, 2001: 214). Organizations should follow transparent employees' appreciation policies at workplace, as appreciation policies are the basis for the career growth of the employees.

Lack of challenging environment: Most employees prefer to perform duties better when the work itself is challenging. Overcoming challenges at work provides self-esteem and confidence among employees. But, if work is monotonous it would cause boredom and would even affect productivity. The study conducted on "Work design and Job Satisfaction" concludes that workers performance is effective when they are satisfied. Essentially, satisfied workers contribute productivity. Therefore, to enhance productivity and quality of work life, the organization shall emphasize on job design, which should include workers autonomy, social 
interaction, and sense of accomplishment through challenging jobs, utilization of a variety of skills of employees and self-evaluation of performance (Onimole, 2015: 206).

2. Ethical practices: Leaders should focus on the following ethical practices at workplace, so that, the employees' job satisfaction is achieved:

Figure 5 represents the essential ethical practices that are to be followed by leaders for ensuring employees' job satisfaction.

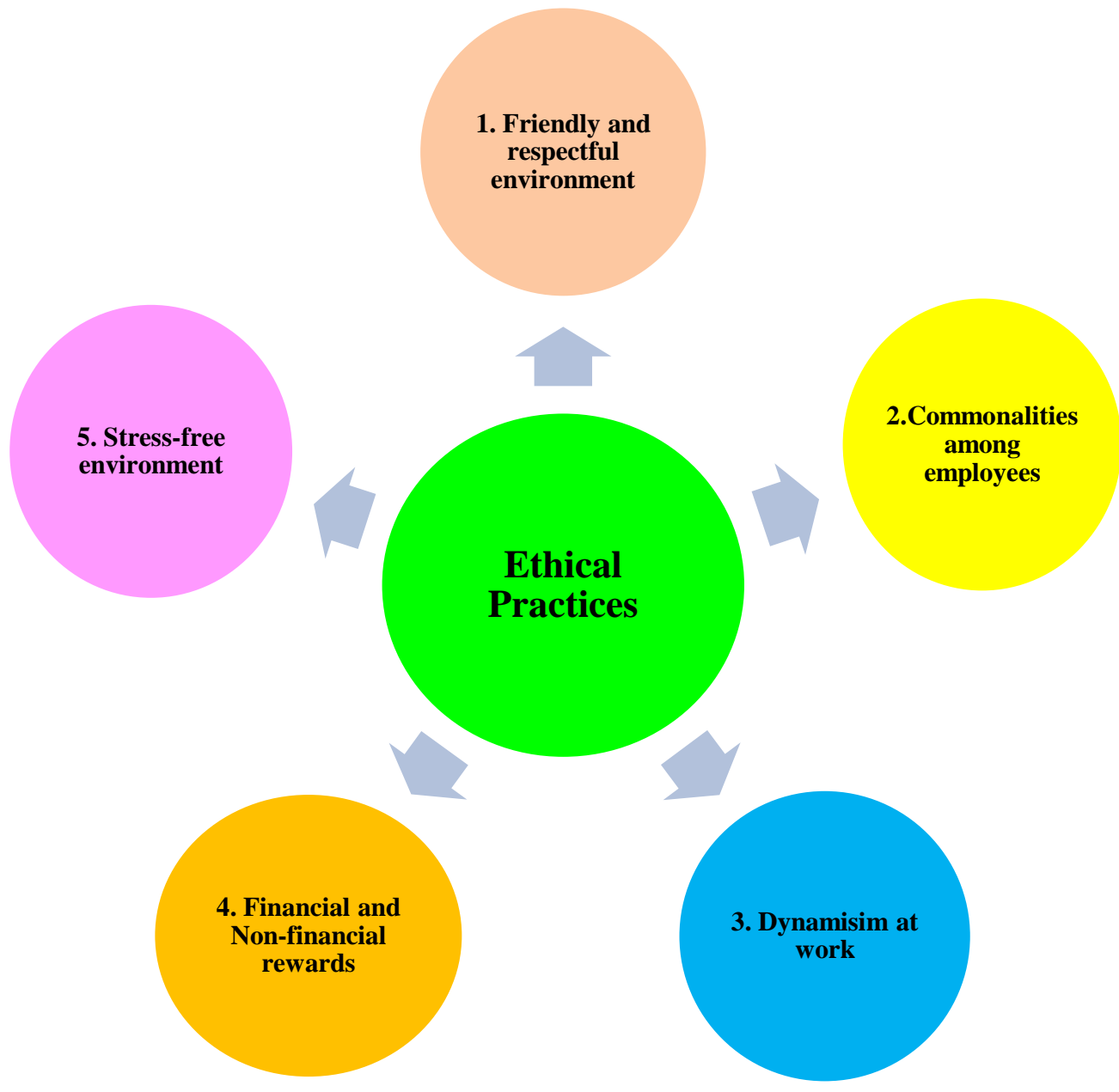

Figure 5. Ethical practices to ensure employees' job satisfaction

Focus on a friendly and respectful environment: Leaders shall focus on creating a friendly and respectful environment, often money is not only the criteria for employees' job satisfaction, though arguably an important criteria to motivate and retain the staff. Reporting to the duties enthusiastically by employees is possible when employees work in a low-stress work environment and more importantly when they find friendly people at work and a respectful environment, these factors would induce them to report to the duties each day. However, motivating the staff starts with being a good manager. Ironically, a company may offer the best pay and benefits, employee-friendly policies and other perks, but if a staff is headed by a bad manager, all these features get neutralize and employees would be demotivating. Respectful treatment of all employees at all levels would be cited as a leading contributing factor to employees' job satisfaction (Harvard Business Review, 2017, Chapter 7). Leaders need to practice and demonstrate standard principles and ethics to ensure the employees are respected, appreciated and are rightly motivated. For leaders, the best way to enforce the ethical mentality in the organization is, to lead it by example.

Focus on commonalities among employees at different levels of management: For ensuring employees' satisfaction at work, leaders shall devise policies for commonalities among peers and reporting managers. The Human resource department during recruitment process should ensure that the commonalities criteria among peers and reporting managers is followed. Commonalities among the staff/managers would result in generating 
more satisfaction to employees at work. When employees get easily connected with co-workers and immediate supervisors a personal relationship is developed. This would help employees to communicate fearlessly the matters concerning the job, and the difficulties that creep cause of diversity among employees can be controlled. In order to mitigate the challenges faced through diversified workforce, organizations usually follow affinity groups strategy. Jeffery (2011: 53) elucidates that, "One popular strategy organizations are using for recruiting and retaining diverse talent is the support of employee network or affinity groups. Affinity groups can be formed around any commonality shared by employees, including ethnicity, age, disability, family status, religion, sexual orientation, and usually, have some association with culture or perspective that has faced challenges in either the society or the organization". However, care should be taken by the management that, the personal relationships do not result in undue leniency by immediate supervisors toward their staff. This challenge can be mitigated by introducing policies that clearly identify the duties and responsibilities of staff and managers working at various levels of management. Leaders, in order to earn trust from their staff, shall introduce the sense of integrity through standard and ethical practices.

Focus on dynamism at work: Leaders shall focus on the autonomy of employees, dynamism in functioning and diversity in the work environment. Dynamism often creates own challenges to the employees and would help them to find out the ways and means to overcome work difficulties. Management should look for different ways to increase the challenges to employees so that new skills are acquired by them. The work that is provided to employees should be in contrast to their daily routines to allow a wide range of responsibilities and subsequently helps them to learn. Developing a challenging environment to employees and permitting them to have a certain amount of autonomy would help them lift their morale and would create a dynamic work environment. Bob and Peter (2010: 74) opine that "All employees need to have a say in how they do their work, to make it more meaningful. When employees find their work meaningful, they become more engaged and effective". In order to ensure dynamism in the organization, leaders are expected to offer out of box thinking solutions to the diverse problems of an organization.

Focus on financial and non-financial rewards: Ethical leaders give due importance to financial and nonfinancial rewards while granting it to their employees. Rationally, when employees receive rewards for performing better, they feel satisfied with their jobs. Non-financial benefits such as a spacious office and other perquisites would significantly increase job satisfaction. Financial benefits such as paid vacations, profit sharing would generate ownership feelings among employees. Both the financial and non-financial incentives would induce employees to work hard and like their job and the organization. Sampath \& Sanjid (2005: 125) say that "The term 'incentive' means an inducement which rouses or stimulates one to action to the desired direction. An incentive has a motivational power; it influences the decision of individuals on putting in efforts towards task performance". The organization should maintain, transparency and fairness consistently while granting financial and non-financial rewards to the employees as this would not only result in settling matters in the most amicable manner with a fairness, justice and equity but would also avoid demotivating the concerned staff.

Focus on the stress-free environment: In organizations, often the cause of stress for employees is the fear of losing their job. For ensuring an ethical environment, leaders shall focus on the stress-free environment. A stress-free environment is bliss to employees. Its characteristics include transparent overall policies, transparent appreciation policies, timely implementation and communication of revised policies. Manikanta Belde (2016: 52) elucidates that, "Many big companies know the importance of relaxation, and so they provide free time to take naps for employees. Companies at present are providing restrooms for relaxation, and this has helped the company's employees become more productive and in turn, helping organizations accomplish success". A stress-free environment would allow employees relieve from undue stress, fatigue, tension and high blood pressure etc. stress-free environment provides not only good health to employees but also contribute a healthy and safe work environment. A stress-free organization is possible only when leaders exhibit care and remain kind to their employees.

\section{Conclusions}

As a conclusion, the study depicts that ethical businesses help in enhancing social welfare. Ethical businesses focus its attention on imparting ethical programs to employees, so that, there is an alignment between organizations preferred values and the values reflected by the behaviors of employees. Ethical businesses always contribute its effort to achieve good corporate governance and help in overcoming employees' ethical dilemmas. Employees' job satisfaction is essential for the success and longevity of the organizations. For achieving employees' job satisfaction, the study suggests that leaders shall remain flexible in their thoughts 
and actions and shall avoid developing indifferences with their staff; they should promote payment of salaries and other benefits that are proportionate with the hard work that the employees undergo for completing the tasks at workplace. Further, leaders shall emphasis on the autonomy of employees, dynamism in functioning and diversity in work environment. Dynamism often creates own challenges to the employees and would help them to find out the ways and means to overcome work difficulties and this will help them to remain motivated. For ensuring an ethical environment, leaders shall focus on the stress-free environment. A stress-free environment is bliss to employees and surely contributes employees' job satisfaction.

\section{References}

1. Almutairi1, Naser N., Alhussaini1, Ahmed N. \& Thuwaini, Shebiab F. (2016). Ethical Leadership Practices: Does It Exist? Do We Care about It? An Evidences from College of Business Studies. International Journal of Business and Management; Published by Canadian Center of Science and Education, 11(7), 130.

2. Alshammari1, Atiya, Almutairi1, Naser N. \& Thuwaini, Shebaib Fahad (2015). Ethical Leadership: The Effect on Employees. International Journal of Business and Management; 10(3), 112. ISSN 1833-3850 EISSN 1833-8119 Published by Canadian Center of Science and Education.

3. Belde, Manikanta (2016). The ultimate stress-free productivity secrets-Get better in Business Life and Relationships. Chennai, India, Notion press, p. 52. Available at: https://books.google.com.om/books?id=Yf67DQAAQBAJ\&pg=PT52\&dq.

4. Bello, Shukurat Moronke (2012). Impact of Ethical Leadership on Employee Job Performance. International Journal of Business and Social Science, 3(11), 234.

5. Blazey, Mark L. (2009). Insights to performance excellence 2009-2010. American Society for Quality, Quality press, Milwaukee, Wisconsin, 53203, p. 85. Available at: https://books.google.com.om/books?id=wSGXJU1XqNMC\&pg=PA9-IA64\&dq.

6. Brown, Michael E., Treviño, Linda K., and Harrison, David A. (2005). Ethical leadership: A social learning perspective for construct development and testing. Organizational Behavior and Human Decision Processes 97, pp. 117-134. Available at: http://users.metropolia.fi/ minnak/ipw/Andrea\%20Rijkeboer/Ethical\%20Leadership\%20Trevino.pdf.

7. Brown, Michael E. and Treviño, Linda K. (2006). Ethical leadership: A review and future directions. The Leadership Quarterly 17, pp. 595-616. Available at: https://www.mcgill.ca/engage/files/engage/ethical_leadership_2006.pdf.

8. Cruell, Gregory L. (2016). The Leaders Capabilities. Lulu publishing services, pp. 21-22. Available at: https://books.google.com.om/books?id=fwu3CwAAQBAJ\&pg=PA21\&dq.

9. Daft, Richard L. (2015). The Leadership experience. Cengage Learning, p. 40. Available at: https://books.google.com.om/books?id=KOfKAgAAQBAJ\&pg=PA40\&dq.

10.Daly, John, Speedy, Sandra and Jackson, Debra (2004). Nursing Leadership. Elsevier Australia, p. 323. Available at: https://books.google.com.om/books?id=TrN3ZS0CNQcC\&pg=PA323\&dq.

11.Dumke, Riccardo (2002). Corporate Reputation and its importance for Business Success- A European Perspective and its implication for Public Relations Consultancies. Diplomica Verlag GmbH, p. 28. Available at: https://books.google.com.om/books?id=Tcx3AQAAQBAJ\&pg=PA28\&lpg=PA28\&dq.

12.Durai, Pravin (2010). Human Resource Management. India, Dorling Kindersley (India) Pvt. Ltd; Pearson Education in South Asia, p. 620. Available at: https://books.google.com.om/books?id=cRAvCCsN2e0C\&pg=PA620\&dq.

13.D' Amato-Neff, Adam Lee (2002). The Muse's Lap-A collection of poetry \& other writings. Writers club press an imprint if iUniverse Inc, Page 267. Available at: https://books.google.com.om/books?id=beG6BAAAQBAJ\&pg=PT267\&dq.

14.Eldakak, Sam (2014). Educational and Ethical Leadership-Best practice, Bloomington, Author House ${ }^{\mathrm{TM}}$ LLC, $\quad$ p. $32 . \quad$ Available at: https://books.google.com.om/books?id=eMBEAwAAQBAJ\&pg=PA32\&dq.

15.Fernando, A.C. (2010). Business Ethics and Corporate Governance. India, Dorling Kindersley (India) Pvt. Ltd, Licensees of Pearson Education in South Asia, Page 2.13. Available at: https://books.google.com.om/books?id=UNKQtwaszhYC\&pg=SA2-PA13\&dq.

16.Fernando, A.C. (2010). Business Ethics and Corporate Governance. India, Dorling Kindersley (India) Pvt. Ltd, Licensees of Pearson Education in South Asia, Page 9.8. Available at: https://books.google.com.om/books?id=_32bJs_nfNIC\&pg=SA9-PA8\&dq. 
17.Ferrell, O.C., Fraedrich, John and Ferrell, Linda (2015). Business ethics: Ethical Decision making and cases. Canada, Cengage Learning, p. $276 . \quad$ Available at: https://books.google.com.om/books?id=A7oaCgAAQBAJ\&pg=PA276\&dq.

18.Harvard Business review (2017). HBR guide to performance management. USA, Harvard Business School Publishing Corporation, $\quad$ Chapter 7 Available https://books.google.com.om/books?id=FG0fDgAAQBAJ\&pg=PT61\&dq.

19.Helms, Ludger (2012). Poor Leadership and bad Governance. Edward Elgar Publishing limited, p. 52. Available at: https://books.google.com.om/books?id=20P_fLri4uUC\&pg=PA52\&dq.

20.Inyang, Benjamin James (2013). Exploring the Concept of Leadership Derailment: Defining New Research Agenda. International Journal of Business and Management; Published by Canadian Center of Science and Education, 8(16), 80 .

21.Kamisan, P. Arif \& King Brian E. M. (2013). Transactional and Transformational Leadership: A Comparative Study of the Difference between Tony Fernandes (Airasia) and Idris Jala (Malaysia Airlines) Leadership Styles from 2005-2009. International Journal of Business and Management; Published by Canadian Center of Science and Education, 8(24), 107.

22.Kooskora, M. and Mägi, P. (2010). Ethical Leadership Behaviour and Employee Job Satisfaction. In: M. Siltaoja, A-M. Lämsä and J.Kujala (eds), Proceedings of the 11th EBEN Research Conference "From Theory to Practice- How Does Business Ethics Matter?" University of Jyväskylä Press, 112 - 126. ISBN: 978951-39-3876-5. Available at: https://www.researchgate.net/publication/263852132 [accessed Oct 13 2017].

23.Levine, David P. (2013). The capacity for ethical conduct: on psychic existence and the way we relate. Sussex, Routledge, Taylor and Francis group, Page ix. Available at: https://books.google.com.om/books?id=Br530938fncC\&pg=PR9\&dq.

24.Mello, Jeffrey A. (2011). Strategic Human resource management. Cengage learning, p. 53. Available at: https://books.google.com.om/books?id=7DYaCgAAQBAJ\&pg=PA53\&dq.

25.Mello, Jeffrey A. (2015). Strategic human resource management. United States of America, Cengage Learning, p. 89. Available at: https://books.google.com.om/books?id=7DYaCgAAQBAJ\&pg=PA89\&dq.

26. Mihelič, Katarina Katja, Lipičnik, Slovenia Bogdan \& Tekavčič, Slovenia Metka (2010). Ethical Leadership. International Journal of Management \& Information Systems - Fourth Quarter 2010, 14(5), 32.

27.Mihelič, Katarina Katja, Lipičnik, Slovenia Bogdan \& Tekavčič, Slovenia Metka (2010). Ethical Leadership. International Journal of Management \& Information Systems - Fourth Quarter 2010 14(5), 33.

28.Mohanty, R.P. (2008). Quality Management Practices, India, Excel books, p. 421. Available at: https://books.google.com.om/books?id=ob2CkTfxF6QC\&pg=PA421\&dq.

29. Mukherjee, Sampat and Basu, Sanjid Kumar (2005). Organization \& Management and Business Communication". New AGE International, (P) limited, Publishers, p. 125. Available at: https://books.google.com.om/books?id=FLz8z8fI-OwC\&pg=PA125\&dq.

30.Mullerat, Ramon (2010). International Corporate Social Responsibility. Kluwer Law International, p. 14. Available https://books.google.com.om/books?id=POKTUI3GyZoC\&printsec=frontcover\&dq=Importance\#v=onep age $\& \mathrm{q}=$ Importance $\& \mathrm{f}=$ false .

31.Nasution, Ade Parluangan, Mahargiono, Ponco Bambang \& Soesatyo, Yoyok (2016). Effect of Leadership Styles, Organizational Climate and Ethos of Work on Employee Productivity (PT. HP Metals Indonesia the Powder Coating). International Journal of Business and Management; Published by Canadian Center of Science and Education, 11(2), 262.

32.Nelson, Bob and Economy, Peter (2010). Managing for Dummies. New Jersey, Wiley Publishing, Inc, Page no: 74. Available at: https://books.google.com.om/books?id=TkDwzBcL0y YC\&pg=PA74\&dq.

33.Olsson Center for Applied Ethics (2012). Why Do Leaders Act Unethically?- opinion of R. Edward Freeman. Available at: http://blogs.darden.virginia.edu/ethicalworld/2012/11/28/why-do-leaders-actunethically/ (Accessed on 10/09/2016).

34.Onimole, S. O. (2015). Work Design and Job Satisfaction. International Journal of Humanities and Social Science, 5(10), 206. Available at: http://www.ijhssnet.com/journals/Vol_5_No_10_October_2015/22.pdf.

35.O' Toole, James and Mayer, Don (2010). Good Business- Exercising effective and ethical leadership. New York, Routledge Taylor \& Francis group, p. 189-190. Available at: https://books.google.com.om/books?id=LMM7NchW8cEC\&pg=PA190\&dq.

36.Painter-Morland, Mollie and Werhane, Patricia (2008). Cutting-edge Issues in Business Ethics. Springer Science + Business Media B.V., p. 38. Available at: https://books.google.com.om/books?id=RsBfMI6di8gC\&pg=PA38\&dq. 
37.Parboteeah, K. Praveen and Cullen, John B. (2013). Business Ethics. New York, Routledge; Taylor and Francis, p. 522. Available at: https://books.google.com.om/books?id=9nkgW2mjd0gC\&pg=PA522\&dq.

38.Payos, Ranulfo P. and Zorilla, Orlando S. (2003). Personnel Management in the $21^{\text {st }}$ Century. Manila, Rex Book store, p. 25. Available at: https://books.google.com.om/books?id=NEcOhzs29tsC\&pg=PA25\&dq.

39.Phillips, Jean M., Gully, Stanley M. (2014). Organizational Behaviour. United States of America, SouthWestern Cengage Learning, p. $85 . \quad$ Available at: https://books.google.com.om/books?id=IcQWAAAAQBAJ\&pg=PA85\&dq.

40.Soieb, Ahmad Zairy Mohd, Othman, Jamilah \& D'Silva, Jeffrey Lawrence (2013). The Effects of Perceived Leadership Styles and Organizational Citizenship Behaviour on Employee Engagement: The Mediating Role of Conflict Management. International Journal of Business and Management; Published by Canadian Center of Science and Education, 8(8), 94.

41.Stern, Larry D. (2006). A Guide to Global Acquisitions. Fultus Corporation, p. 111. Available at: https://books.google.com.om/books?id=51yIX5pJ-k0C\&pg=PA111\&dq.

42.Tóth, Gergely (2009). The Truly Responsible Enterprise: About unsustainable development, the tools of Corporate Social Responsibility (CSR) and the deeper, strategic approach. KÖVET Association for Sustainable Economies, p. 18. Available at: https://www.researchgate.net/publication/277327488.

43.Velasquez, Manuel, Andre, Claire, Thomas Shanks, Thomas S.J., and Meyer, Michael J. (2010). What is Ethics? MCAE- The Markkula Center for Applied Ethics. Available at: https://www.scu.edu/ethics/ethicsresources/ethical-decision-making/what-is-ethics/ (Accessed on 14/09/2017).

44.Vetumbuavi Mungunda- Standard Bank Namibia's Chief Executive (2015). Ethical leadership can prevent fraud, corruption. New Era Newspaper, Namibia. Available at: https://www.newera.com.na/2015/07/31/ethical-leadership-prevent-fraud-corruption/ (Accessed on 15th September, 2016).

45.Walker, Gary S. (2001). IT Problem Management. Prentice hall PTR, p. 214. Available at: https://books.google.com.om/books?id=yhSTT9pdMCcC\&pg=PA214\&dq. 